\title{
Establishment and Growth of Potato Micro-Cuttings in Sand Trays
}

\author{
Md. Jahangir Hossain ${ }^{1}$, Mosammat Shamsun Nahar ${ }^{1,2}$ \\ ${ }^{1}$ Research Wing, Bangladesh Agricultural Research Institute, Joydebpur, Bangladesh; ${ }^{2}$ Plant Pathology Section, Horticulture Re- \\ search Center, Bangladesh Agricultural Research Institute, Joydebpur, Bangladesh. \\ Email: dr.jahangir2011@yahoo.com
}

Received February $8^{\text {th }}, 2012$; revised March $16^{\text {th }}, 2012$; accepted April $19^{\text {th }}, 2012$

\begin{abstract}
Two separate experiments were conducted to evaluate the success of the establishment and growth of micro-cuttings of potato $(5-6 \mathrm{~cm}$ tall) in sand trays [38 cm (L) $\times 28 \mathrm{~cm}(\mathrm{~W}) \times 7.5 \mathrm{~cm}(\mathrm{H})$ plastic trays] under controlled environment $\left(22^{\circ} \mathrm{C} \pm 2^{\circ} \mathrm{C}, 60-75 \mu \mathrm{mosm}^{-1} \cdot \mathrm{s}^{-1}\right.$ light energy for $16 \mathrm{~h}$ daily). In the first experiment, micro-cuttings of potato cv. Diamant were planted at six populations $(500,600,700,800,900$ and 1000 cuttings per tray) in treated sand (sun dry, $1 \%$ formaldehyde, $0.2 \%$ Dithane M-45 and control). The mortality percentage of micro-cuttings was nil for sun dry sand while formaldehyde and dithane M-45 treated sand had $1 \%-4 \%$ against $15 \%$ in the control with the highest population density. Mortality of micro-cuttings in formaldehyde and dithane M-45 treated sand trays were found not to be related to pathogenic organism rather toxic effect of these two chemicals. Micro-cuttings in Sun dry and control treatments showed better growth performance than these in chemically treated sand trays. In the second experiment, urea @ 1, 2 and $3 \mathrm{~g}$ per tray was applied as solid form after 15 days of planting the micro-cuttings and as liquid form @ $0.5,1$ and $2 \%$ solution sprayed in the micro-cuttings repeatedly after $15,30,45$ and 60 days of planting. The micro-cuttings which received urea as solid state died within 2 - 3 days and 2\% urea solution was also detrimental. Urea solution@ @ $0.5 \%$ found to be very effective for vegetative growth of micro-cuttings in sand trays. The control was also good for vegetative growth but at a slower rate.
\end{abstract}

Keywords: Sand Tray; Sun Dry; Fungicides; Urea Fertilizer; Plant Population; Growth; Potato Micro-Cuttings

\section{Introduction}

Potato is an important food crop worldwide. It is mainly a temperate zone crop, though it is cultivated in many tropical countries during the winter season. It is reported that potato seed accounts for $>50 \%$ of the total cost of production [1-3]. Moreover, better seed can produce better crop and higher yield. Availability of quality seed tubers is the important factor for better crop and tuber yield. Potato crop is prone to about 50 diseases [4-6], of which about $8-10$ are major diseases though others caused considerable losses of this crop [7]. The fungal and bacterial diseases could be controlled or minimize by applying chemicals while viruses or viroids diseases are uncontrollable. Once a plant is infected by virus or viroid, it carried over generations through seed tubers and caused degeneration of this crop and yield loss. Many countries of the world are trying to use different planting materials as seeds for producing quality seed potatoes [8-11]. Production of nucleus seed stock with in vitro micro-plant is prime important as this material is pathogen-tested (P.T.). The different planting materials like top shoot cutting $[9,12,13]$, nodal cuttings [9,14], sprout cuttings [15] are used to increase the nucleus seed stock within the shortest period. Ewing [16] used "slips" in vermiculite to produce pathogen-tested minitubers, while Vietnamese farmers used pathogen tested micro-plants followed by repeated cuttings in Delat region in order to develop the low cost planting materials to be used in plains for seed potato production [17]. Commercial tissue culture laboratories rather used to propagate planting materials under ex vitro conditions under controlled environment in order to save energy, money, chemicals, etc. The present work was aimed to standardize the methods for better establishment and growth of micro-cuttings of potato in sand trays under controlled environment.

\section{Materials and Methods}

Micro-cuttings of three Dutch potato cultivars Cardinal, Diamant and Multa were used in two separate experiments to standardize the methods for better establishment and growth in sand trays under controlled environment during 2006 and 2007. 
In the experiments in vitro micro-plants $(4-6 \mathrm{~cm}$ tall) of 30 days old were first transplanted in plastic trays of $38 \mathrm{~cm}(\mathrm{~L}) \times 28 \mathrm{~cm}(\mathrm{~W}) \times 7.5 \mathrm{~cm}(\mathrm{H})$ contained 0.013 $\mathrm{mm}$ size sand particle. The transplanted micro-plants were nursed under controlled environment $\left(22^{\circ} \mathrm{C} \pm 2^{\circ} \mathrm{C}\right.$, $60-75 \mu \mathrm{mosm}^{-1} \cdot \mathrm{s}^{-1}$ light energy for $16 \mathrm{~h}$ daily). After 25 days of planting, top shoots $(1.5-2.0 \mathrm{~cm})$ were cut and planted in sand trays of above.

In the first experiment, only one cv. Diamant was used. Sand were treated with four different (sun dry, $1 \%$ formaldehyde solution, $0.2 \%$ dithane M-45 and untreated control) ways. Sand at $5 \mathrm{~cm}$ heap were sun dried for two days while sand were treated with formaldehyde and dithane M- 45 before 7 and 3 days respectively of planting the micro-cuttings. Micro-cuttings population (500, $600,700,800,900$ and 1000 per tray which was equivalent to $4750,5700,6650,7600,8550$ and $9500 \mathrm{~m}^{-2}$ ) was maintained (Figure 1(a)). The sand trays were kept under the controlled environment as stated previously. The experiment was laid in a randomized complete block design with four replications. The experiments were set on 15 April in both the years, 2006 and 2007.

In the second experiment, three Dutch potato cultivars Cardinal, Diamant and Multa were used. Urea @ 1, 2 and $3 \mathrm{~g}$ per tray in solid form and $0.5,1$ and $2 \%$ urea solution were applied to standing crop of micro-cuttings. No urea

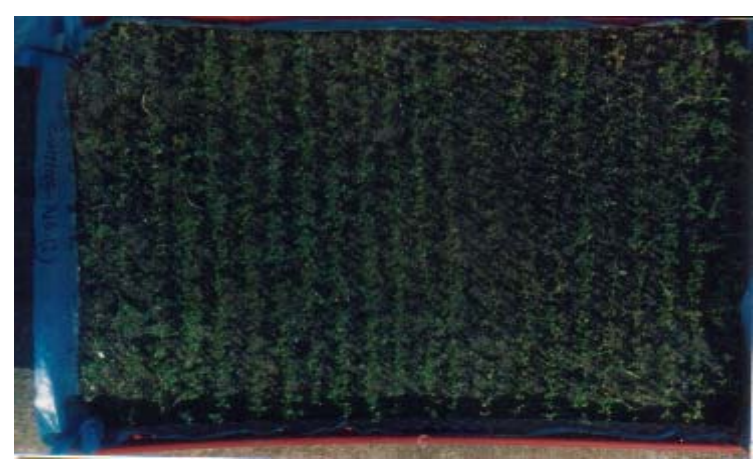

(a)

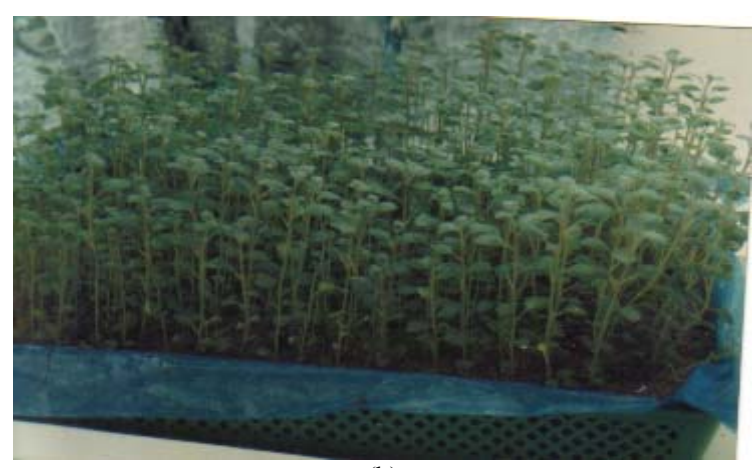

(b)

Figure 1. Planting of (a) mother plants in sand tray $(38 \mathrm{~cm}$ $\times 28 \mathrm{~cm} \times 7.5 \mathrm{~cm}$ ) at a plant population of 1000 per tray and (b) luxuriant growth of microplants after four sprays of $0.5 \%$ urea solution at 60 days period. was used in the control trays. Urea in solid form was applied 15 days after planting the micro-cuttings in sand trays, while spraying of urea solution started after 15 days of planting the micro-cuttings and sprayed for four times at 15-days interval. The experiment was set in a randomized complete block design with three replications. The experiments were set on June 20 in both the years, 2006 and 2007.

As the recorded data on different parameters of both the experiments conducted in two years, 2006 and 2007 did not vary statistically, thus the mean data were used to analyse the experiment.

\section{Results}

Results of treated sand contained in plastic trays and population on establishment and growth of micro-cuttings of potato are presented in Table 1. The mortality rate of micro-cuttings was nil for sun-dry sand, which was statistically superior. About $1.38 \%$ and $1.53 \%$ micro-cuttings were died in formaldehyde and dithane M-45 treated sand, respectively while control trays had $4.83 \%$ which was statistically inferior. Micro-cuttings took 12 - 15 days for developing new shoots. The chemically treated sand required more number of days than the others. After 25 days of planting the micro-cuttings, the plantlets attained the maximum height of about $10 \mathrm{~cm}$ for sun-dried sand or in control treatment compared to about $6.0 \mathrm{~cm}$ for chemically treated sand. Within this period, each plantlet developed approx. 6 leaves. The longest leaf was developed in $1 \%$ formaldehyde-treated sand which was statistically similar to $0.2 \%$ dithane M- 45 , while sun-dry and control treatment were almost equal. Rate of node production was the best for sun dry sand and other three were statistically similar but inferior. In case of internode length, sun-dry and control treatment were almost equal and the chemically-treated sand were statistically similar but inferior. Similar trend was also shown for the number of roots per micro-cuttings and length of the longest roots. No disease incidence was observed in sun dry sand and the control treatment had the maximum (Table 1).

The mortality of micro-cuttings was increased with increasing plant population. Similar trend was observed for plant height while other parameters except longest leaf were found to be unaffected due to varied plant population. Leaf size was higher for lower population.

Table 2 shows the results of urea management for micro-cuttings and plant development. Solid application of urea in sand and $2 \%$ foliar spray caused cent percent plant died in all the three cultivars. Urea sprayed @ $0.5 \%$ solution was found to be most effective for micro-cuttings survival while $1 \%$ spray was also detrimental which caused dead of micro-cuttings up to $40 \%$. Micro-cuttings sprayed with $0.5 \%$ urea solution were found to have 
Table 1. Effect of different treatments of sand and plant population on establishment and growth of potato micro-cuttings of potato cv. Diamant (mean of two years, 2006 and 2007).

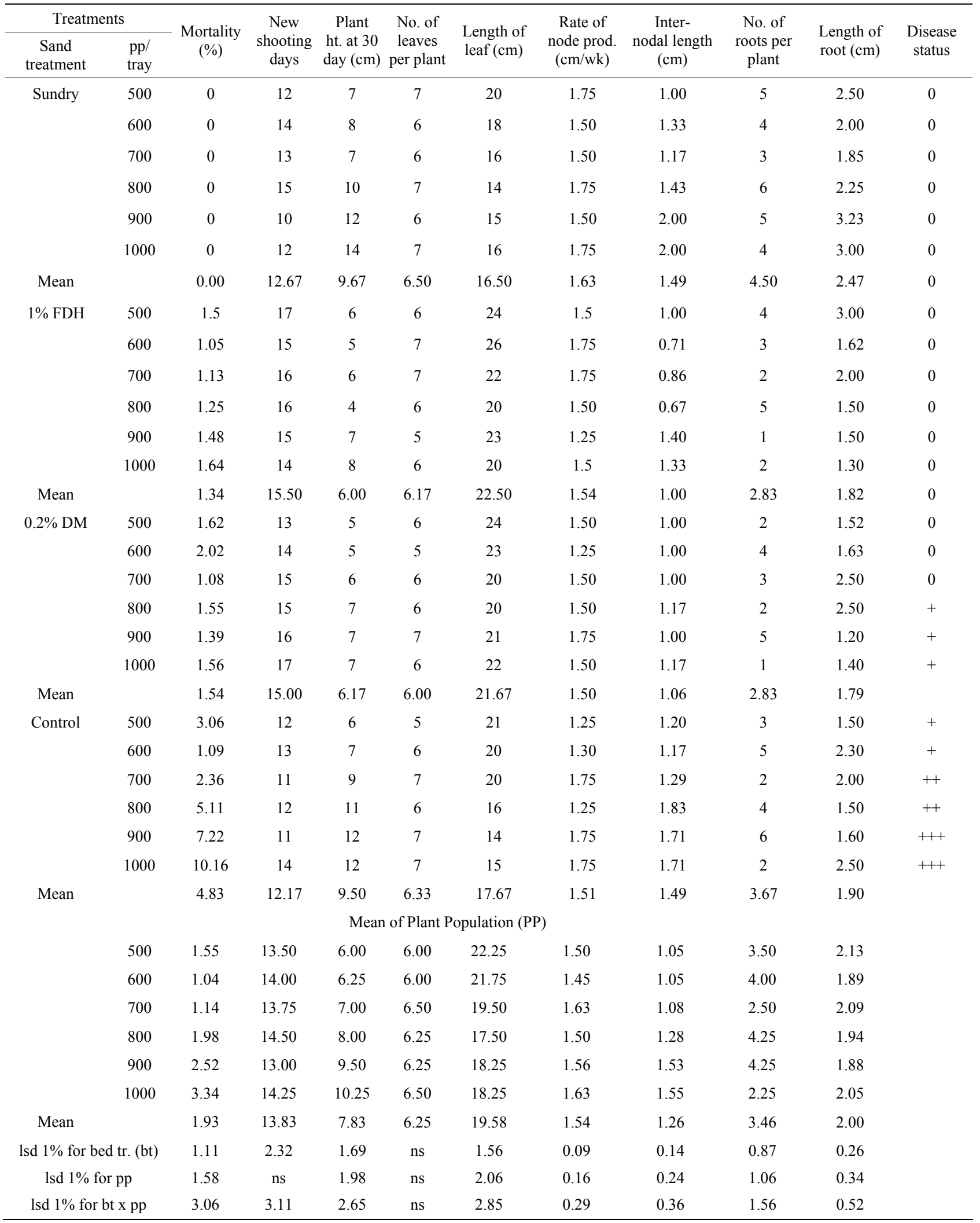

Note: $\mathrm{FDH}=$ Formaldehyde, DM = Dithane M-45; pp = Plant population; +-.---.---.- $\rightarrow+++=$ Degree of incidence. 
Table 2. Effect of urea on micro-cuttings of three potato cultivars planted in sundried sand (mean of two years, 2006 and 2007).

\begin{tabular}{|c|c|c|c|c|c|c|c|c|c|c|c|}
\hline Cultivars & Urea dose & $\begin{array}{l}\text { Plant } \\
\text { survival } \\
(\%)\end{array}$ & $\begin{array}{l}\text { No. of leaf } \\
\text { per plant }\end{array}$ & $\begin{array}{l}\text { Length of } \\
\text { leaves }(\mathrm{mm})\end{array}$ & $\begin{array}{l}\text { Plant } \\
\text { height } \\
(\mathrm{cm})\end{array}$ & $\begin{array}{l}\text { Inter-nodal } \\
\text { length }(\mathrm{cm})\end{array}$ & $\begin{array}{l}\text { Growth rate } \\
(\mathrm{mm} / \text { day })\end{array}$ & $\begin{array}{l}\text { Node prodn } \\
\text { rate (no/wk) }\end{array}$ & $\begin{array}{c}\text { Dry wt. } \\
\text { shoot (\%) }\end{array}$ & $\begin{array}{l}\text { Dry wt. } \\
\text { root (\%) }\end{array}$ & $\begin{array}{l}\text { Ratio } \\
\text { (shoot: } \\
\text { root) }\end{array}$ \\
\hline \multirow[t]{7}{*}{$\mathrm{V}_{1}$} & $1 \mathrm{~g} /$ tray & 0 & 0 & 0 & 0 & 0 & 0 & 0 & 0 & 0 & 0 \\
\hline & $2 \mathrm{~g} /$ tray & 0 & 0 & 0 & 0 & 0 & 0 & 0 & 0 & 0 & 0 \\
\hline & $3 \mathrm{~g} /$ tray & 0 & 0 & 0 & 0 & 0 & 0 & 0 & 0 & 0 & 0 \\
\hline & $0.5 \% \mathrm{FS}$ & 100 & 9 & 20 & 13 & 1.44 & 4.33 & 2.10 & 11.6 & 21.2 & 0.55 \\
\hline & $1.0 \% \mathrm{FS}$ & 40 & 6 & 15 & 11 & 1.83 & 3.66 & 1.40 & 10.2 & 22.1 & 0.46 \\
\hline & $2.0 \% \mathrm{FS}$ & 0 & 0 & 0 & 0 & 0 & 0 & 0 & 0 & 0 & 0 \\
\hline & control & 100 & 6 & 13 & 9 & 1.50 & 3.00 & 1.40 & 13.4 & 21.6 & 0.62 \\
\hline Mean & & 34.29 & 3.00 & 6.86 & 4.71 & 0.68 & 1.57 & 0.70 & 5.03 & 9.27 & 0.23 \\
\hline \multirow[t]{7}{*}{$\mathrm{V}_{2}$} & $1 \mathrm{~g} /$ tray & 0 & 0 & 0 & 0 & 0 & 0 & 0 & 0 & 0 & 0 \\
\hline & $2 \mathrm{~g} /$ tray & 0 & 0 & 0 & 0 & 0 & 0 & 0 & 0 & 0 & 0 \\
\hline & $3 \mathrm{~g} /$ tray & 0 & 0 & 0 & 0 & 0 & 0 & 0 & 0 & 0 & 0 \\
\hline & $0.5 \%$ FS & 100 & 12 & 16 & 14 & 1.17 & 4.67 & 2.80 & 10.9 & 23.1 & 0.47 \\
\hline & $1.0 \% \mathrm{FS}$ & 20 & 9 & 12 & 10 & 1.11 & 3.33 & 2.10 & 10.2 & 22.6 & 0.45 \\
\hline & $2.0 \% \mathrm{FS}$ & 0 & 0 & 0 & 0 & 0 & 0 & 0 & 0 & 0 & 0 \\
\hline & control & 100 & 7 & 14 & 11 & 1.57 & 3.67 & 1.64 & 12.5 & 23.2 & 0.54 \\
\hline Mean & & 31.43 & 4.00 & 6.00 & 5.00 & 0.55 & 1.67 & 0.93 & 4.80 & 9.84 & 0.21 \\
\hline \multirow[t]{7}{*}{$\mathrm{V}_{3}$} & $1 \mathrm{~g} /$ tray & 0 & 0 & 0 & 0 & 0 & 0 & 0 & 0 & 0 & 0 \\
\hline & $2 \mathrm{~g} /$ tray & 0 & 0 & 0 & 0 & 0 & 0 & 0 & 0 & 0 & 0 \\
\hline & $3 \mathrm{~g} /$ tray & 0 & 0 & 0 & 0 & 0 & 0 & 0 & 0 & 0 & 0 \\
\hline & $0.5 \%$ FS & 100 & 11 & 17 & 13 & 1.18 & 4.33 & 2.57 & 12 & 22.6 & 0.53 \\
\hline & $1.0 \% \mathrm{FS}$ & 32 & 7 & 14 & 10 & 1.43 & 3.33 & 1.63 & 10.4 & 21.1 & 0.49 \\
\hline & $2.0 \% \mathrm{FS}$ & 0 & 0 & 0 & 0 & 0 & 0 & 0 & 0 & 0 & 0 \\
\hline & control & 100 & 7 & 11 & 10 & 1.43 & 4.33 & 1.63 & 10.8 & 22.3 & 0.49 \\
\hline \multirow[t]{9}{*}{ Mean } & & 33.14 & 3.57 & 6.00 & 4.71 & 0.57 & 1.57 & 0.83 & 4.74 & 9.43 & 0.22 \\
\hline & \multicolumn{2}{|c|}{ Mean of urea doses } & & & & & & & & & \\
\hline & $1 \mathrm{~g} /$ tray & 0.00 & 0.00 & 0.00 & 0.00 & 0.00 & 0.00 & 0.00 & 0.00 & 0.00 & 0.00 \\
\hline & $2 \mathrm{~g} /$ tray & 0.00 & 0.00 & 0.00 & 0.00 & 0.00 & 0.00 & 0.00 & 0.00 & 0.00 & 0.00 \\
\hline & $3 \mathrm{~g} /$ tray & 0.00 & 0.00 & 0.00 & 0.00 & 0.00 & 0.00 & 0.00 & 0.00 & 0.00 & 0.00 \\
\hline & $0.5 \% \mathrm{FS}$ & 100.00 & 10.67 & 17.67 & 13.33 & 1.26 & 4.44 & 2.49 & 11.50 & 22.30 & 1.20 \\
\hline & $1.0 \% \mathrm{FS}$ & 30.67 & 7.33 & 13.67 & 10.33 & 1.46 & 3.44 & 1.71 & 10.27 & 21.93 & 1.07 \\
\hline & $2.0 \% \mathrm{FS}$ & 0.00 & 0.00 & 0.00 & 0.00 & 0.00 & 0.00 & 0.00 & 0.00 & 0.00 & 0.00 \\
\hline & control & 100.00 & 6.67 & 12.67 & 10.00 & 1.50 & 3.67 & 1.56 & 12.23 & 22.37 & 1.32 \\
\hline Mean & & 32.95 & 3.52 & 6.29 & 4.81 & 0.60 & 1.65 & 0.82 & 4.86 & 9.51 & 0.51 \\
\hline
\end{tabular}

$\mathrm{V}_{1}=$ Cardinal, $\mathrm{V}_{2}=$ Diamant and $\mathrm{V}_{3}=$ Multa; Tray size: $38 \mathrm{~cm} \times 28 \mathrm{~cm}, \mathrm{FS}=$ Foliar spray, sundried sand. 
better growth performance than $1 \%$ solution and control treatment. The cv. Diamant with $0.5 \%$ urea foliar spray gave better performance for most of the parameters compared to the other two cultivars. Within two months period, the micro-cuttings of the cv. Diamant attained the maximum of $14 \mathrm{~cm}$ plant height to develop the maximum of 12 leaves per plant [Figure 1(b)]. The cv. Cardinal had the longest leaf of $20 \mathrm{~mm}$. Internodal length $(\mathrm{cm})$, plant growth rate $(\mathrm{mm} /$ day) and node production rate (no./week) were also the highest with $1 \%$ foliar spray in Cardinal $(1.83 \mathrm{~cm})$; and $0.5 \%$ foliar spray in Diamant $(4.67 \mathrm{~mm} /$ day and 2.80 per week respectively). Urea (a) $0.5 \%$ foliar spray or the control treatment produced the maximum dry matter in shoots and roots. These two treatments were also produced the maximum shoot to root ratio.

\section{Discussion}

The treatments of sand were found to be very effective in reducing plantlet mortality. Effectiveness of sun-dry in reducing micro-organisms from the soil was reported earlier [18]. In the present investigation, sand was dried under natural sun light for $48 \mathrm{hrs}$. ( 8 hrs daily). This treatment seemed to be very effective in eliminating all organisms from sand. On the other hand, $1 \%$ formaldehyde treatment was found to eradicate micro-organisms from sand, though on the average $1.34 \%$ plantlet died, may be due to toxic effect of formaldehyde. In vitro developed micro-plants are usually very soft and succulent. Sand was treated with $1 \%$ formaldehyde 10 days before transplanting the micro-cuttings. Formaldehyde toxicity caused damaged of roots within $2 / 3$ days. No disease causing organism was detected in formaldehyde treated sand. Dithane M-45 is a fungicide, active against late blight of potato. This was also used to eradicate so many fungus as reported earlier [19]. Dithane M-45 also eradicates organisms from sand to some extent. Disease incidence was observed with high population but the incidence was not so severe, probably this chemicals checked severity of the organism. The plantlets of the control treatment was seriously affected by micro-organism, which arose with increasing plant population. With the highest plant population, $10.16 \%$ micro-plants were died. The attack was observed at patch. The pathological study showed that the organisms were Fusarium oxysporum and Fusarium solani caused damping off disease to the micro-plants, which is indicative that normal sand are not always safe for hardening practices of in vitro microplants.

Plant mortality was increased with increasing plant population. Increased plant population may be enhanced microbial development. Mainly fusarium oxysporum and fusarium solani were found to cause damping off disease to the micro-plants in sand $[2,6,19]$.
New growth of the micro-cuttings was appeared earlier in sun dry and control treatment compared to the chemically treated sand, which probably affected adversely the new growth. Plant height was also shown similar trend across the treatments. Development of leaf per plant and their size was found not to be affected due to treatment of sand by formaldehyde or Dithane M-45. For most of the parameters like rate of node production and internodal length were significantly better for sun-dry and control treatment compared to chemically treated sand. Similarly, the number and length of roots were significantly better for sun-dry sand. These two parameters probably, negatively affected by formaldehyde or Dithane M-45 [20].

Solid application of urea at all the three levels (1, 2 and $3 \mathrm{~g}$ per tray) was found to be fetal to the micro-cuttings. Solid application of urea in sand probably reached the root zone of the slender micro-plants before any transformation which is necessary for making the available form $\left(\mathrm{NH}^{+} / \mathrm{NO}_{2}^{+}\right)$. And as such, it became toxic to the micro-plants. On the other hand, urea solution above $0.5 \%$ was also detrimental. Kabir and Chowdhury sprayed $1 \%-5 \%$ urea solution at foliage of normal potato crop at 30 days age and obtained 3\% solution most effective and $>3 \%$ was detrimental [21]. Urea solution $(0.5 \%)$ spraying was found to be most effective for growth and development of the micro-cuttings and the micro-cuttings under control treatment was also good, though some percentage of micro-plants were died. Urea solution@1\% caused dead of 40\% - 60\% micro-cuttings and the growth of survived micro-plants was also hampered which was inferior to control treatment. Internodal length, plant growth rate and node production rate was significantly higher for $0.5 \%$ foliar spray of urea while dry matter production of shoot and root was lower compared to control which indicates that urea caused lowering of DM\% in shoot and root of micro-cuttings [4,22]; their ratio was also higher in control treatment than $0.5 \%$ or $1 \%$ urea foliar spray.

\section{Conclusion}

From the above discussion it may be concluded that sundry sand is the most effective soil substrate for development and growth of micro-plants under controlled environment and spraying of $0.5 \%$ urea solution on foliage can safely be done to enhance the growth of micro-cuttings.

\section{REFERENCES}

[1] M. J. Hossain, M. A. Akhtaruzzaman, N. Sultana and M. M. Rashid, "Effect of Seed Size and Plant Spacing on the Growth and Yield of Potato," Journal of Agricultural Research, Vol. 17, 1992, pp. 42-47.

[2] J. Fajardo, N. Lutaladia, M. Larinde, C. Rosell, I. Barker, 
W. Roca and E. Chujoy, "Quality Declared Planting Material, Protocols and Standards for Vegetatively Propagated Crops," FAO Plant Production and Protection Paper 195, 2010, pp. 71-78.

[3] T. S. Roy, M. J. Hossain, S. Akhter, M. I. Akhter and T. Nishizawa, "Performance of Ten Promising True Potato Seed Progenies over Generations," Journal of Agricultural Research, Vol. 30, 2005, pp. 159-166.

[4] P. M. Harris, "The Potato Crop: The Scientific Basis for Improvement," Chapman and Hall, London, 1982, pp. 546-573.

[5] D. E. Vander Zaag, E. Asscheman, J. A. Bokx, H. Brinkman, C. B. Bus, P. H. Hotsma, C. P. Meijers, A. Mulder, K. Scholte, L. J. Turkensteen and R. Wustman, "Potato Diseases: Diseases, Pests and Defects," Netherlands Potato Consultative Group (NIVAA), Holland, 1997, pp. $1-85$.

[6] F. Laemmlen, "Damping-Off Diseases," University of California, ANR Publication 8041, 2001, pp. 1-4.

[7] J. A. de Bokx, "Viruses of Potato and Seed Potato Production," Centre for Agricultural Publishing and Documentation, Wageningen, 1972.

[8] Anonymous, "The Garden Helper: Planting Methods for Growing Potatoes (Part Two)," Manual for Potato Gardening, 2012, p. 1.

[9] J. E. Bryan, M. G. Nelson and M. T. Jackson, "Stem Cuttings, a Rapid Multiplication Technique for Potatoes," CIP Slide Training Series, Guide-Book I (3), International Potato Center, Lima, 1981, p. 35.

[10] M. J. Hossain, M. S. Nahar and A. U. Ahmed, "Sprout and Top-Shoot Cutting for Rapid Multiplication of Potato in Bangladesh," The Journal of Agricultural Science, Vol. 132, No. 4, 1999, pp. 437-443. doi: $10.1017 / \mathrm{S} 0021859699006565$

[11] Q. B. Miguel, J. E. Bryan, M. T. Jackson and M. G. Nelson, "Leaf-Bud Cuttings: A Rapid Multiplication Technique for Potatoes," CIP Slide Training Series, Guide Book I (4), International Potato Center, Lima, 1981, p. 24.

[12] M. J. Hossain and M. Zakaria, "Annual Research Report on Tuber Crops Tissue Culture of 1999-2000," Tuber Crops Research Centre, BARI, Gazipur, 2000, pp. 1-14.

[13] H. Wei and P. V. Zaag, "Potato (Solanum spp.) Apical Cutting Production and Their Agronomic Potential," Asian Potato Journal, Vol. 2, No. 1, 1991, pp. 17-22.

[14] M. J. Hossain, "Tubers from Leaf-Bud and Apical-Bud Cuttings: Methods for Rapid Clonal Propagation of Potato in Bangladesh," Field Crops Research, Vol. 35, No. 2, 1993, pp. 147-148.

[15] M. J. Hossain, and V. Vecchio, "Potential of Sprout Cutting on the Growth, Yield and Multiplication Rate of Potato," Italian Journal of Agronomy, Vol. 3, No. 1, 1999, pp. 1-6.

[16] E. E. Ewing, "Use of Potato Cuttings to Study Tuberisation Stimulus in Andigena Population," American Journal of Potato Research, Vol. 52, 1976, pp. 1-7.

[17] N. V. Uyen and P. V. Zaag, "Vietnamese Farmers Use Tissue Culture for Commercial Potato Production," American Journal of Potato Research, Vol. 60, No. 11, 1983, pp. 873-879. doi:10.1007/BF02853978

[18] T. K. Dey, A. H. M. Jafar, A. L. Khan and M. S. Ali, "Prevalence of Seed-Borne Fungi of True Potato Seed (TPS) in Bangladesh," Journal of the Indian Potato Association, Vol. 20, 1993. pp. 87-90.

[19] Anonymous, "Annual Report of Tuber Crops Research Centre of 1996-97," Bangladesh Agricultural Research Institute, Joydebpur, pp. 35-47.

[20] R. C. Rowe, "Potato Health Management: The American Phytopathological Society," APS Press, Minnesota, 1993, pp. 1-178.

[21] M. H. Kabir and A. J. M. E. H. Chowdhury, "Foliar Spray of Urea Solution for Improving Growth and Yield of Potato," Journal of the Indian Potato Association, Vol. 21, 1989, pp. 113-117.

[22] M. S. Islam, S. Razia and K. M. Hossain, "Soil Test Crop Response Correlation Studies for Potato," Proceedings of the 4th Workshop of Potato Research Workers, 8-10 September 1981, pp. 44-48. 